\title{
Five-Membered Heterocyclic Ring Via Dichalcones
}

\author{
N.G.Ahmad and O.Th.Ali \\ University of Mosul, College of Education, Dept.of chemistry, Mosul-Iraq
}

E-mail: Natiq.ahmad@yahoo.com

\section{الخلاصة}

تم في هذه الدر اسة تحضيرمركبات ثنائية الجالكون (4-12) من التفاعل بين البنزال

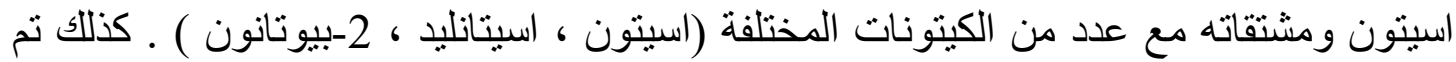

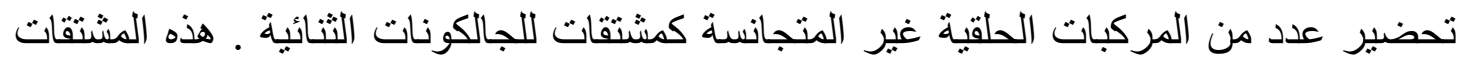

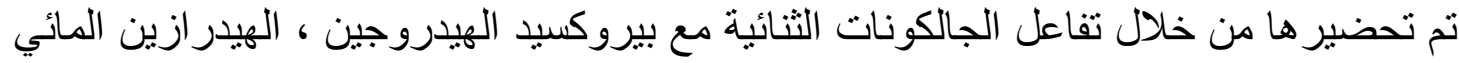
و اليوريا للحصول على مركبات الاوكسير ان (13-213) ، البايرازولين (22-30) و والبريميدينينون جئ. جميع المركبات المحضرة تم تشخيصها بالطرق الفيزياوية المتوفرة والطرق الطيفية (درجة الانصهار ، طيف IR ، طيف UV وبعض الكثوفات المختبرية ) واخيرا نوضيح الفعالية البايولوجية المتوقعة لبعض من المركبات .

\section{ABSTRACT}

In this study some of dichalcone compounds (4-12) were prepared by the reaction of benzalacetone and its derivatives with a number of different ketones (acetophenone, acetanilide, 2butanone). Also a number of heterocyclic compounds were prepared as a derivatives of that dichalcones, these derivatives were prepared by the reaction of dichalcone with hydrogen peroxide, hydrazine hydrate and urea to produce oxirane compounds (13-21), pyrazolines (22-30) and pyrimidinones (31-40) respectively. All the synthesised compounds were characterized by the available physical and spectral methods (melting point, I.R. and U.V. spectrum as well as laboratory tests). Finally the expected biological effects of some compounds were investigated.

\section{Introduction:}

The members of chalcone and flavonid family have attracted a great deal of interest due to their applications as antibacterial , anti-inflammatory and anticancer pharmacological agentsr ${ }^{[1-3]}$. 


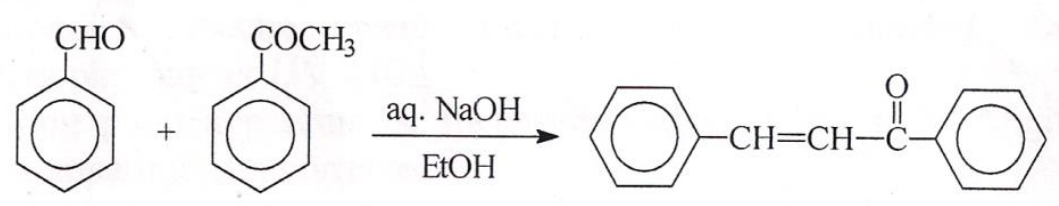

Dibenzal acetone chalcone and some of its derivatives are important intermediates in the synthesis of many pharmaceuticals. They are commonly synthesized via the Claisen-Schmidt condensation between acetophenone and benzaldehyde. This reaction is catalyzed by acids and bases under homogeneous conditions. There is another type of chalcones called dichalcone compounds ${ }^{[4]}$, as dibenzal acetone [1,5-Dipheny 1-1,4-pentadiene-3 -one]

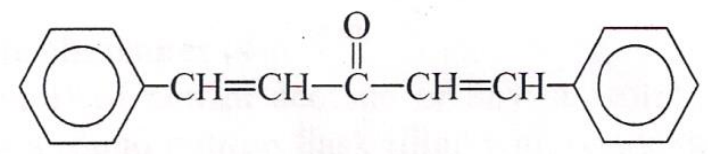

\section{[1,5-Dipheny1-1,4-pentadiene-3-one]}

which was prepared from the reaction of two molecules of benzaldehyde and one molecule of ketone (like acetone) through double condensation reaction. In this work one mole of substituted benzaldehyde were condensed with one mole of acetone in basic condition and the resulted chalcone were condensed with one mole of another ketone (acetophenone, acetanalyde, and 2-butanone),so the solid colored products are dichalcones and their substituents are collected and directed to produce many derivatives which have an important applications in pharmacy and industries.
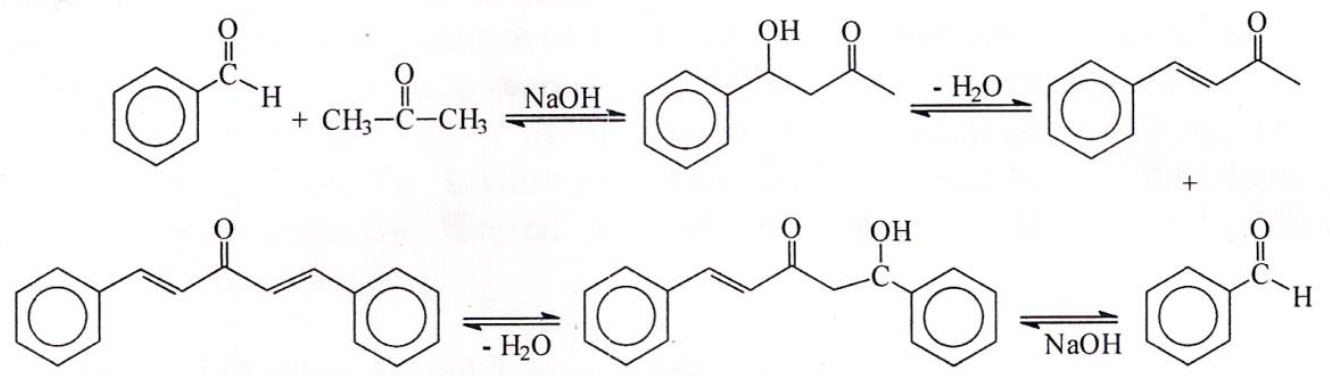

Oxiranes compounds were obtained when these chalcones react with peroxides in basic media These compounds have many biological and industrial importance. pyrazolens are very important heterocyclic compounds ${ }^{[6]}$, produced from the reaction of chalcones with hydrazine, phenyl hydrazine and substituted hydrazines. Pyrimidinones are obtained from the reaction of chalcones with urea and substituted urea in the presence of sodium ethoxide ${ }^{[7]}$. 


\section{EXPRIMENTAL}

1. Infrared spectra were taken used:Pye Unicam SP 1100 Infrared spectrophotometer.

2. Ultraviolet spectra were taken used Shimadzu Double-Beam spectro photometer UV-210A

3. Melting point apparatus is: Electrothermal IA 9300 series Digital Melting-point apparatus, (uncorrected).

\section{preparation of chalcones :}

preparation of benzal acetone and their substituntes $(1-3)^{[8]}$

A mixture of $10 \mathrm{ml}$ (10\% sodium hydroxide) and $70 \mathrm{ml}$ of acetone were putted in flask and stirred magnetically at (20$25)^{\circ} \mathrm{C}$ in a water bath. A mixture of $(0.26 \mathrm{mo} 1,14.5 \mathrm{gm})$ of freshly distilled of benzaldehyde or any substituted one and ethanol was putted in a beaker and added drop-wise onto the flask with continuous stirring for 45 minutes Filter the precipitated products, washing with cold water until the filtrate is neutral, then dry the precipitate after recrystallization from ethanol.

preparation of double chalcones (4-12) $)^{[9-10]}$

A solution of $(0.21 \mathrm{~mol})$ of benzal acetone or any substituted one and $(25 \mathrm{ml})$ of ethanol were putted in a round bottom flask filled with condenser and magnetic stirrer, stirred and warmed, then excess of $10 \%$ sodium hydroxide were added with $(0.2$ mol) of any ketone (acetophenone, acetanalyde or 2-butanone) with stirring and refluxing for (15-24 hrs). On cooling the mixture using ice bath a yellow crystal products were obtained. Filter the precipitate, wash with cold water until neutralization, collect the product, dry after recrystallization from ethanol.

preparation of Epoxy chalcones (oxiranes)(13-21 ${ }^{[11-13]}$

In around bottom flask, a mixture of $(1 \mathrm{ml})$ of $(10 \%)$ sodium hydroxide and $(0.1$ mole $)$ of $(30 \%)$ hydrogen peroxide were added with continuous stirring using magnetic stirrer, a hot solution of (0.1 mole) of the dichalcone (4-12) dissolved in $(10 \mathrm{ml})$ ethanol. After complete addition, the mixture stirred for ( $3 \mathrm{hrs})$ at room temperature, then after $(24 \mathrm{hrs})$ the precipitate was filtered ,washed with water until the neutralization and recrystallized from ethanol.

preparation of (3-alkyl-5-aryl-2-pyrazoline)(22-30) $)^{[14-15]}$

In a round bottom flask fitted with magnetic stirrer dissolve (0.005 mol) of any double chalcone (4-12) , and add $(0.05 \mathrm{~mol}$ $, 0.05 \mathrm{~g})$ of hydrazine hydrate with stirring for $(6 \mathrm{hrs})$ at room 
temperature. Filter the produced precipitate and wash with water then recrystallize from ethanol.

preparation of 4-alkyl-6-aryl-1,2,6-trihydropyrimidine-2(1H) one(3140) $[16-17]$

In a round bottom flask fitted with condenser and magnetic stirrer, dissolve $(0.01 \mathrm{~mol})$ of any compound (4-12) in $(25 \mathrm{ml})$ of absolute ethyl alcohol, then add drop-wise a solution of $(0.01 \mathrm{~mol}$, $0.3 \mathrm{~g}$ ) of urea and sodium ethoxide, reflux for $(24 \mathrm{hrs})$, cool the mixture and add cold water to form the precipitate, filter the product and recrystallize from ethanol.

\section{RESULTS AND DISCUSSION}

The chalcones are examples of $\alpha, \beta$-unsaturated carbonyl compounds ${ }^{[18]}$. Conjugation between carbonyl group and two double bonds with large extent of than monochalcones. In this work the double chalcones (4-12) were prepared through Claisen-Schmidet condensations of one mole of benzalacetone or their substituted ones with one mole of any ketones in the presence of sodium hydroxide solution. The structures of the prepared compounds were investigated by measuring some physical constants and spectroscopic study (I.R \& U.V). The infrared spectra shows a band at $1636-1650 \mathrm{~cm}^{-1}$ due to the stretching of carbonyl group which indicate a decrease of $\left(38 \mathrm{~cm}^{-1}\right)$ in comparison with that band of monochalcones ${ }^{[19]}$, and this is because of the more extent of conjugation, this increase of conjugation will cause the lowering the force constant of the band and so lowering the band place ${ }^{[20]}$. The U.V. spectra give an absorption of $\lambda_{\max }$ at $(327-380 \mathrm{~nm})$ for the $n \rightarrow \pi^{*} \& \quad \pi \rightarrow \pi^{*}$ excitation, and because of the conjugation between the carbonyl group and the double bonds a red pathochromic shift was noticed .

\section{Epoxy chalcones:}

Because of the importance of the oxiranes (epoxy chalcones) in industry and pharmacy, a number of these compounds were prepared as a derivatives of the chalcones (412) through the reaction of the chalcone with hydrogen peroxide in the presence of sodium hydroxide. The I.R. spectra give a band of absorption at $\left(992-1033 \mathrm{~cm}^{-1}\right)$ due to the stretching of $(\mathrm{C}-\mathrm{O}-$ C) in the peroxide ring and an absorption at $\left(1669-1675 \mathrm{~cm}^{-1}\right)$ of the stretching of the carbonyl group in addition to the band at (1621-1628 $\left.\mathrm{cm}^{-1}\right)$ due to the $(\mathrm{C}=\mathrm{C})$. We notice in this spectra that there is an increase shift in the magnitude of absorption of the carbonyl group in comparison with that of the prepared double chalcones (4-12) and this indicate the disappear of the conjugation in 
one of the two ends between the carbonyl group and one double bond. Pyrazoline compounds and their substitutes have grate importance not less than oxiranes, so these compounds were prepared by the reaction between chalcones (4-12) and hydrazine hydrate at room temperature. The I.R. spectra indicate the disappearance of the stretching band of the carbonyl group and the appearance of a new band at the frequency $\left(1613-1617 \mathrm{~cm}^{-1}\right)$ which is due to the stretching band of $(\mathrm{C}=\mathrm{N})$ in addition to the new band at (3341-3360 $\left.\mathrm{cm}^{-1}\right)$ of the $(\mathrm{N}-\mathrm{H})$ group, and this indicate the formation of the five membered ring of pyrazolines. 4-Alkyl-6-aryl-1,3,6trihydropyrimidinone-2-one were prepared by the reaction of dichalcones with urea in the presence of sodium ethoxide in absolute ethanol. The I.R. spectra shows a sharp absorption at (1648-1670 $\left.\mathrm{cm}^{-1}\right)$ for the stretching of the carbonyl group, in addition to the new bands at $\left(\left(3476-3500 \mathrm{~cm}^{-1}\right)\right.$ of the $(\mathrm{N}-\mathrm{H})$ stretching and the band at $\left(1573-1591 \mathrm{~cm}^{-1}\right)$ of the $(\mathrm{C}=\mathrm{N})$ stretching, the appearance of these bands indicate the formation of pyrimidinone ring.

Table(1): Some physical and spectral data for some compounds

\begin{tabular}{|c|c|c|c|c|c|c|c|c|c|c|c|c|}
\hline Co & \multirow[b]{2}{*}{$X$} & \multirow[b]{2}{*}{$\mathrm{R}$} & \multirow[b]{2}{*}{$\begin{array}{c}\text { m.p. } \\
{ }^{\circ} \mathrm{C}\end{array}$} & \multirow[b]{2}{*}{$\begin{array}{c}\text { Yield } \\
\%\end{array}$} & \multicolumn{7}{|c|}{ IR $(\mathrm{KBr}), \mathrm{cm}^{-1}$} & \multirow{2}{*}{$\begin{array}{c}\mathrm{UV} \\
\text { (etanol) } \\
\Lambda_{\max }\end{array}$} \\
\hline $\begin{array}{l}\text { mp. } \\
\text { No. }\end{array}$ & & & & & $\mathrm{C}=\mathrm{O}$ & $\mathrm{C}=\mathrm{C}$ & $\begin{array}{c}\text { Ar-C- } \\
\mathrm{H}\end{array}$ & $\begin{array}{c}\text { Ar- } \\
\mathrm{C}=\mathrm{C}-\end{array}$ & $\mathrm{C}-\mathrm{O}-\mathrm{C}$ & $\mathrm{C}=\mathrm{N}$ & $\mathrm{N}-\mathrm{H}$ & \\
\hline 1 & $\mathrm{H}$ & - & $39-42$ & 65 & 1696 & 1639 & - & - & - & - & - & 330,290 \\
\hline 2 & $4-\mathrm{OCH}_{3}$ & - & $80-82$ & 77 & 1684 & 1632 & - & - & - & - & - & 340,293 \\
\hline 3 & 4-CI & - & 184-186 & 70 & 1679 & 1628 & - & - & - & - & - & 335,296 \\
\hline 4 & $\mathrm{H}$ & $\mathrm{Ph}-\mathrm{C}-\mathrm{CH}_{3}$ & 70 & 88 & 1650 & 1610 & 3045 & 1588 & - & - & - & 350,295 \\
\hline 8 & $4-\mathrm{OCH}_{3}$ & $\mathrm{Ph}-\mathrm{NH}-\mathrm{C}-\mathrm{CH}_{3}$ & 49 & 65 & 1645 & 1614 & 3075 & 1597 & - & - & - & 340,293 \\
\hline 12 & 4-CI & $\mathrm{CH}_{3}-\mathrm{C}-\mathrm{C}_{2} \mathrm{H}_{5}$ & 63 & 83 & 1636 & 1580 & 3030 & 1593 & - & - & - & 327,297 \\
\hline 13 & $\mathrm{H}$ & $\mathrm{Ph}-\mathrm{C}-\mathrm{CH}_{3}$ & 119 & 60 & 1669 & 1621 & - & - & 992 & - & - & - \\
\hline 17 & $4-\mathrm{OCH}_{3}$ & $\mathrm{Ph}-\mathrm{NH}-\mathrm{C}-\mathrm{CH}_{3}$ & 178 & 78 & 1670 & 1628 & - & - & 1017 & - & - & - \\
\hline 21 & 4-C1 & $\mathrm{CH}_{3}-\mathrm{C}-\mathrm{C}_{2} \mathrm{H}_{5}$ & 140 & 59 & 1675 & 1625 & - & - & 1033 & - & - & - \\
\hline 22 & $\mathrm{H}$ & $\mathrm{Ph}-\mathrm{C}-\mathrm{CH}_{3}$ & 104 & 67 & - & - & - & - & - & 1615 & 3341 & - \\
\hline 26 & $4-\mathrm{OCH}_{3}$ & $\mathrm{Ph}-\mathrm{NH}-\mathrm{C}-\mathrm{CH}_{3}$ & 160 & 65 & - & - & - & - & - & 1617 & 3350 & - \\
\hline 30 & 4-C1 & $\mathrm{CH}_{3}-\mathrm{C}-\mathrm{C}_{2} \mathrm{H}_{5}$ & 108 & 52 & - & - & - & - & - & 1613 & 3360 & - \\
\hline 31 & $\mathrm{H}$ & $\mathrm{Ph}-\mathrm{C}-\mathrm{CH}_{3}$ & 111 & 50 & 1670 & - & - & - & - & 1591 & 3483 & - \\
\hline 35 & $4-\mathrm{OCH}_{3}$ & $\mathrm{Ph}-\mathrm{NH}-\mathrm{C}-\mathrm{CH}_{3}$ & 154 & 61 & 1648 & - & - & - & - & 1573 & 3500 & - \\
\hline 40 & 4-CI & $\mathrm{CH}_{3}-\mathrm{C}-\mathrm{C}_{2} \mathrm{H}_{5}$ & 135 & 49 & 1651 & - & - & - & - & 1573 & 3476 & - \\
\hline
\end{tabular}

\section{BIOLOGICAL STUDY}

This study included the effect of some prepared compounds on four types of bad effected bacteria. Some prepared compounds were tested on the growth of this deferent types of negative and positive gram dye using sensitivity test method 
(disk diffusion method). The following types of bacteria are used :(Escherichia coli, Klebsiella pneumonia, Pseudomonas aeruginosa. Bacillus subtilis). Bauer ${ }^{(21)}$ method is adopted in the sensitivity test for its easiness and economic use of used nutrient medium. Four colonies of the previous types of bacteria were hosted in a nutrient broth which is enoccupated at $37{ }^{\circ} \mathrm{C}$ for 20 hrs and diluted with normal saline $0.1 \mathrm{ml}$ of the solution is taken to a nutrient agar and being spread on the dish surface. Agricultured dishes were lefted for 30 minutes, to measure the biological activity for some prepared compounds, a filtered paper is prepared, sterilized and soaked in the prepared solution of the various concentrated prepared solutions. DMSO was used as a solvent. The following standard anti-biotics were used (Cephalaxine (keflex), Oxacillin, Ampcilline) as controllers according to what is being used in the general health laboratory which depend on the world health organization ${ }^{(22)}$. 
Table(2): Biological activity of compounds $(5,6,7,8,9,10,12,14)$

\begin{tabular}{|c|c|c|c|c|c|}
\hline \multirow{2}{*}{$\begin{array}{c}\text { Comp. } \\
\text { No. }\end{array}$} & \multirow[b]{2}{*}{ Conc. } & \multicolumn{4}{|c|}{ Test organisms } \\
\hline & & Pseudomonas & Klebsiella & E. coli & Bacillussubtilis \\
\hline \multirow{4}{*}{5} & 10 & 12 & 12 & 16 & 12 \\
\hline & 1 & 10 & 12 & 13 & 11 \\
\hline & 0.1 & 9 & 9 & 12 & 8 \\
\hline & 0.01 & - & 7 & 8 & - \\
\hline \multirow{4}{*}{6} & 10 & 11 & 11 & 12 & 13 \\
\hline & 1 & 9 & 10 & 9 & 8 \\
\hline & 0.1 & 8 & 8 & - & 7 \\
\hline & 0.01 & - & - & - & - \\
\hline \multirow{4}{*}{13} & 10 & 13 & 12 & 17 & 16 \\
\hline & 1 & 11 & 11 & 15 & 13 \\
\hline & 0.1 & 8 & 9 & 11 & 5 \\
\hline & 0.01 & 6 & 7 & - & - \\
\hline \multirow{4}{*}{14} & 10 & 15 & 13 & 12 & 14 \\
\hline & 1 & 13 & 12 & 9 & 8 \\
\hline & 0.1 & 11 & 9 & 7 & - \\
\hline & 0.01 & 9 & - & - & - \\
\hline \multirow{4}{*}{15} & 10 & 1 & 12 & 13 & 12 \\
\hline & 1 & 9 & - & 10 & 8 \\
\hline & 0.1 & - & - & 9 & - \\
\hline & 0.01 & - & - & - & - \\
\hline \multirow{4}{*}{22} & 10 & 14 & 13 & 13 & 13 \\
\hline & 1 & 13 & - & 10 & 9 \\
\hline & 0.1 & 9 & 7 & 9 & 7 \\
\hline & 0.01 & - & - & - & - \\
\hline \multirow{4}{*}{24} & 10 & 13 & 12 & 15 & 13 \\
\hline & 1 & 12 & - & 12 & 11 \\
\hline & 0.1 & - & - & - & - \\
\hline & 0.01 & - & - & - & - \\
\hline \multirow{4}{*}{32} & 10 & 12 & 14 & 13 & 2 \\
\hline & 1 & & 11 & 10 & 11 \\
\hline & 0.1 & - & - & - & - \\
\hline & 0.01 & - & - & - & - \\
\hline \multicolumn{2}{|c|}{ Oxacillin } & 13 & 12 & 11 & \\
\hline \multicolumn{2}{|c|}{ Cephaloxine } & 10 & 8 & 13 & 12 \\
\hline \multicolumn{2}{|c|}{ Ampcilline } & 12 & 11 & 8 & \\
\hline
\end{tabular}


<smiles>[X]c1cccc(C=O)c1</smiles><smiles>[X]c1ccc(C2OC2C(=O)C=O)cc1</smiles>

13-21<smiles>[X]c1ccccc1C1CC(C=[R])=NC(=O)N1</smiles>

$33-40$

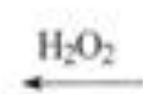<smiles>[X]c1ccc(C=CC(=O)C=O)cc1</smiles>

$4-12$

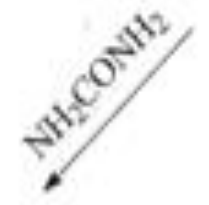<smiles>[X]c1ccccc1C1CC(C=O)=NN1</smiles>

$22-30$

$\mathrm{X}=\mathrm{H}, 4-\mathrm{OCH}_{3}, 4-\mathrm{Cl}$

$\mathrm{R}=\mathrm{Ph}-\mathrm{C}-\mathrm{CH}_{3}, \mathrm{Ph}-\mathrm{NH}-\mathrm{C}-\mathrm{CH}_{3}, \mathrm{CH}_{5}-\mathrm{C}-\mathrm{C}_{2} \mathrm{H}_{5}$

Scheme -1- : synthetic route of the prepared compounds (1-40) 


\section{REFERENCES}

1) S.F.Nielsen,S.B.Christensen,G.Cruziani,A.Kharazmi,T.Lilij efors, J.Med.Chem .41(1998), 4819.

2) M.Liu,P.Wilairat,M.L..Go,J.Med.Chem.44,(2001),3335.

3) J.Rojas, J.N.Dominguez, J.E.Charris , G.Lobo, M.L.Ferrandiz, Eur.J.Med. Chem.37,(2002),699.

4) H.D. Durst and G.W. Gokel, "Experimental Organic Chemistry", McGraw-Hill, Inc., 371, 374, 375, 376, (1980).

5) R.A. Osisanya and J.O. Oluwodiya, J. Heterocyclic Chem., 26, (1989).

6) M.T.A., M.Z., S.A.S., alrafiden sci.J. (2001)12,1,53-59.

7) V.F. Sedova, V.N.A. Seevan and V.P. Mamqev, Nauk, Ser. Khim., 4, 91-97, (1973); Chem. Abstr., (1973), 79, 105180.

8) A.I. Vogel, "Textbook of Practical Organic Chemistry", $4^{\text {th }}$ ed., Longman, London, 796, 345, (1978).

9) D.W. Maass, D.H. Polytech, .1. Eng. Chem. Soc., 9, 4386, (1963).

10) R. Dalpozzo, A. Denino, E. Intorno, "A new protocol for the synthesis of a,(3-unsaturated 1,3-diketones", Tetrahedron, 53, 7, 2585-2590, (1997).

11) N.H. Cromwell, R.E. Bamlurg and R.P. Barkly, J. Am. Chem. Soc., 81, 4294, (1959).

12) N.C. Yang and R.A. Jinnegan, Am, Chem. Soc., 80, 5845, (1958).

13) M.T.A., M.Z., S.A.S., alrafiden sci.J. (2000)11,4,36-43.

14) N.R. El-Rayyes and N.H. Bahtiti, .1. Heterocyclic Chem., 26, 209, (1989). A. Levai, J. Heterocyclic Chem., 39, 1. (2002).

15) Tanimoto, Shigeo, Murao, Yoshikazu, oda, Ryohei, J. Jap. Chem. Soc., 66, 48-50, Kyoto, Japan, (1963).

16) A.L. Marzinzik and E.R. Felder, J. Org. Chem., 63, 723, (1998).

17) I.M.A. Thannoun, M.Sc. Thesis, University of Mosul, Iraq, (1999).

18) L.J. Bellamy, "The Infrared Spectra of Complex Molecules", Chapman and Hall Ltd., London, 149-152, (1978).

19) V.M. Parikh, "Absorption Spectroscopy of Organic Molecules", Addison-Wesley Publishing Co., 62, 22, 245, (1974).

20) C. Guofeng, L. Jitai, D. Huiyum and L. Tongshuang, "Ultrasound-induced synthesis of 1,5-diaryl-1,4pentadiene-3-ones", Key Lab. of Analytical Science and Technology", China, (2003).

21) A.W. Bauer, W.A.M. Kirby, J.S. Sherris and M Turk, Am. J. Clin. Pathol., 45, 493-496, (1966).

22) J. Vandepitte, K. Engbac, P. Pico and G. I feuk, "Basic Laboratory Procedure in Clinical Bacteriology", World Health Organization, Geneva, 78-85, (1991). 